International Journal of English Literature and Social Sciences
Vol-6, Issue-4; Jul-Aug, 2021
Journal Home Page Available: $\underline{\text { https://ijels.com/ }}$
Journal DOI: $10.22161 /$ ijels

Peer-Reviewed Journal

\title{
Liberalizing the Kitchen from Women
}

\author{
Anishika Kapoor
}

Amity Institute of English Studies and Research, Amity University, Noida, India

Received: 11 Jun 2021; Received in revised form: 07 Jul 2021; Accepted: 14 Jul 2021; Available online: 27 Jul 2021

(C)2021 The Author(s). Published by Infogain Publication. This is an open access article under the CC BY license

(https://creativecommons.org/licenses/by/4.0/).

\begin{abstract}
In this advancing and ever-changing world, certain things still stand stagnant when it comes to women. Food has always been related to women, and has acted as a significant form of gender socialization throughout the centuries, helping to ensure the subordination of women and the gender role division of labour which exists even today.

Why do women have to do majority of the cooking? What role does food play in constructing our identities as men and women? Why having equality in doing kitchen chores is still an expectation and not an understanding between man and wife? These are the sort of unsettling standard sanctimony that are associated with food and women. The culinary literature of the fifties acted as perfect rule books for the American society to convey the gender roles and responsibilities, which were established on their basis.
\end{abstract}

Keywords-American Culinary Culture, Cookbooks, Women's Identity

\section{INTRODUCTION}

Traditionally, women always have been associated with food and its preparation. It has always been gender coded as effeminate and seen as a woman's job to do. According to the ideals of the American society, kitchen has always been the perfect arena for a woman to showcase her skills and artistic talents. Sherrie A. Inness, through her book Dinner Roles: American Women and Culinary Culture, takes us on a gastronomical journey exploring the ideas related to representation of women and cooking in the American society. The book argues that popular culinary literature provided a recipe for women's and men's behavior. She also sheds light on the representation of women through media, which casts doubts on a woman's femininity if she is not interested in cooking or cooking related tasks. Society in it itself made sure to keep giving a constant reminder to women that kitchen was their "natural" place. They acted as a rule book of the societal norms for women and (men), teaching them their outright gender roles expected from them to be played in the society.

Through the examination of the primary texts, light will be shed on the personification of women and cooking. Women's relationship to food and its preparation has been a significant form of gender socialization throughout the centuries, helping to ensure the subordination of women and the gender role division of labor which exists even today. Women are expected to prepare the food on a daily basis no matter how tedious it might get for them whereas men are expected to take up this responsibility if the food happens to be 'manly' such as barbecue and grilled steak. From grocery shopping, devising menus, setting up table, dealing with the leftovers, making the meals aesthetically pleasing and nutritious to maintaining the kitchen with all its ensemble is all a woman's job to do.

The second argument of the paper will be about what role does cooking related tasks play in shaping a woman's role in the society.

The research paper will be showcasing how culinary culture and media worked hand in hand to help us understand how cooking-related tasks helped in shaping a woman's role in the society and the cultural expectations about what it means to be a woman. How culinary literature became a source to teach women lessons about how they were envisioned to behave and conveyed them that their "proper" place was in the kitchen only. Cooking 
became an important tool in identification of women: if she is "sufficiently womanly or not" (Inness,4).

The norm that all women, whatever their economic or ethnic background is, should naturally be the ones responsible for cooking, is a patriarchal construct. This has been a powerful influence in shaping the expectations and gender roles for men and women. The traditional connection between women and food preparation has been authenticated prominently over the decades. The picture has not changed much even in the "liberated times" because a woman is envisaged to juggle between marriage, work and domesticity. The equality in kitchen chores between husband and wife is an expectation and not an understanding.

Laura Shapiro in Perfection Salad: Women and cooking at the Turn of the Century, talks about how home economists ignored the ethnic and regional foods for baked beans, salads and sweets, influencing women to give away the fresh ingredients and modify to convenience foods. They also insisted that a woman should only cook by following a recipe. She carries this thought forward with her Something from the Oven: Reinventing Dinner in 1950's America, where she talks about the famous personalities like Julia Child, Betty Crocker, Poppy Canon who broke the conspiracies of the media corporations and other influences who reminded women of the fresh ingredients, which they took special care of, while cooking them. The use of these convenience foods depicted that women were incapable of mastering the simplest cooking techniques, which was insinuated as an insult to women.

In her autobiography of Julia Child, she showcases the quintessential American who with her irrepressible sense of humor, wit and a passion for good food, she ushered in the America's culinary renaissance and became its chief icon. Through her TV show, "The French Chef" she convinced and taught Americans that they could master the art of French cooking in an era where cooking shows were not popular on television. Laura Shapiro also talks about other famous personalities in her book Julia Child and how they created an impact on the American audience.

The popular culinary literature played an important role in shaping the way American society perceives the relationship between food and women. It has been devised by the wide range of texts written from cookbooks to articles in women's magazines. It outlined kitchen work as naturally rewarding to women emotionally and aesthetically, while catering to the assumptions of men's masculinity being intact when they visited the kitchen. As Inness in Dinner Roles backs these arguments by giving ample examples of cookbooks that were put together for both men and women telling them their respected roles and assuring men about their masculinity time to time.

Cookbooks played an important role in shaping the roles and responsibilities of women and men about cooking. They maneuvered as a medium for reassuring male readers that cooking is not an endeavor that will make them effeminate. They created a hierarchy between men and women's cooking skills, stating that men's cooking was a form of art, while women's cooking was much lower on the scale of prestige. As George L. Moose points out in his book, The image of man: the creation of modern masculinity (1996), in a society where presenting a masculine image and, thus, asserting one's manhood has been an "all pervasive" concern, the connection between femininity and cooking has assured that men continue to look at the kitchen as a women's territory (Moose,3).

Food products were brought into play to showcase masculinity and femininity. Creaminess and sweetness were perceived as traits of femininity. Fluffy frippery marshmallow and maraschino Jell-O salad were feminine foods. Meat was rendered as a "natural" connection between men and food, building assumptions about food, shaping our culture, and our expectations about gender roles. It was connected with high status, a potent signifier of manliness, and a way to gain power over the subordinates(women), (Inness, 20-29).

Emphasizing on male competence assured them that kitchen duties were simple tasks, not "real" work at all, privileging the world of workplace and trivializing the domestic realm of the kitchen. Even in 1955, Steven Bauer (writing for Glamour) felt a need to address the perceived femininity of cooking: like playing the flute or doing needle-point, cooking has long been seen as something that feminizes men (Bauer,236). As is the case in Caryl Churchill's Top Girls where the lead character Marlene, competent and efficient worker who gets promoted above a man, later in the play, is confronted by that man's wife who asks her to step down from the post, so the man can acquire it, and Marlene should be a subordinate.

Another method that was adopted by men's cookbooks was sexualizing men's cooking. Paul K. Tibbens'sCookin' for the Helluvit (1950) featured sketches of scantily clad beauties to bedeck his collection of recipes, which had names like "hot dish" (59) and "luscious tomato" (Tibbens,134). Williamson and Kelly's named their recipes like Billy Graham's Missionary Chicken (58-59). These cookbooks sexualized cooking for men by taking it straight to the bedroom from the kitchen where men have traditionally demonstrated and affirmed their masculinity. 
Men's cookbooks and articles portrayed a clear vision about foods that were suitable for a man to prepare, cook and eat.

A clear conflict of thought processes was seen during this time between the writers, as some were busy residing by the assumptions created by the cookbooks and some were busy being an eye-opener through their works for the society. Writers like Achmed Abdullah and John Kenny, through their cookbooks, asserted that cooking was a man's artistic province, a masculine craft. On the other hand, writers like Fredric A. Birmingham and Barbara Haber, reassured readers that they would not become "sissies" if they cooked. Birmingham adjured his readers to "reverse the feminine trend in cooking" and to "recognize that cooking is a man's prerogative" (Birmingham,3).

The perception of cooking has always been very different for both men and women. The society created an awful divide between the sexes by using "cooking or cooking-related tasks" as a bait, to form the gender coded relationship between food and women. As culinary historian Barbara Wheaton writes, "cookbooks are like a magician's hat: one can get more out of them than they seem to contain" (Barbara,2). To understand how adults came to hold the very definite ideas about cooking and its relationship to gender, we must turn to the lessons that boys and girls learn about food and cooking while young. The media played an important part in it and created captivating theories to inculcate the ideals of the society from the very start. Like men's cookbooks, juvenile cookbooks did more than to teach how to grill a steak or bake a cake; it demonstrated the attitude that the society expected children to adopt towards cooking and tasks related to it. It was an intriguing genre which was used as a bait to teach kids not only cooking but to form an ideology about sex roles, (Inness,37-38).

Early century juvenile cookbooks which were meant for the kids, persuaded the theories about cooking being a woman's job in kids since early age. Juvenile cookbooks disseminated this idea in many ways, mostly by targeting girls, not boys as their "natural" audience.

There were books specifically addressed to girls which outnumbered books that were written for both. The large number of cookbooks and other forms of culinary literature that addressed girls, not boys, supported a culture in which cooking was supposed to be a girl's "natural" employment.

The illustrations on the cookbooks conveyed the unspoken message of the girls as "cooks" and the boys as "consumers", creating an ideology that cooking was not a male activity. Fleck's A First Cook Book for Boy's and
Girl's included numerous pictures of girl's cooking and boys eating the delicacies they dished up. Mary Blake's Fun to Cook Book (1955) featured a cover illustration of a small girl cooking.

In the nineteenth century, juvenile cookbooks such as Elizabeth Stansbury Kirkland's Six Little Cooks or, Aunt Jane's Cooking Class (1877) were a way to pass down recipes and cooking lessons, primarily to girls. Peggy Hoffman's Miss B. 'sFirst Cookbook: Twenty Family-Sized recipes for the Youngest cook (1950) prepared young girls to follow in their mother's footsteps. Such books and articles made clear that cooking was a girl's domain.

According to juvenile cookbooks, boys and girls were to have distinctly different food preferences. Boy's, like men, were expected to have hearty foods whereas girl's, like women, were supposed to enjoy sweet, delicate or dainty foods. As Kiene perceives in The Step-by-Step Cook Book for Girl's and Boy's, “Girls may excel in pastries, and so forth, but boy's want food that stick to the ribs" (34).

There were recipes that conveyed young readers what food tastes they were expected to adopt. Boys were expected to have little or no interest in food's appearance as long as it appeals to their taste buds; girls, however were supposed to be concerned about the presentation of food. This belief went beyond presentation of food, women were expected to be concerned about attractiveness in all areas of their lives from home to their personal appearance. This concern is one of the main signifiers of femininity. Thus, cookbooks were not just teaching a lesson about creamed potatoes; they were also giving additional subtle lessons on how femininity was constituted. Creaminess and sweetness were considered as feminine traits. These gendered tastes continue to serve as one of the many ways that boys and girls (men and women) display their gender identification today. When a woman orders a salad for lunch and a man orders grilled steak, they are not only satisfying their hunger but also expressing their gender.

Juvenile cookbooks also gave girls other culinary advices, like cooking let girls demonstrate that they were learning the "correct" feminine habits that they would require as adult women. The Betty Betz Teen-Age Cookbook (1953) informed its readers: "Remember that the good-looking girl who's also a 'good cooking girl' stands more of a chance of sniffing the blossoms!" (Betz,1). The writer was teaching a great deal more than how to cook; she was also teaching girls lessons about gender behavior that were expected to last a lifetime.

Cooking was seen as the best bait to catch boys, if a girl knew her cooking skills well, she could allure a lot of boys. 
Culinary literature in the early 1900 s not only taught women to make tea sandwiches and decorating teacakes but also how to be ladylike and feminine. It taught women the concept of daintiness and how it was applied in every aspect of her life. Daintiness seems omnipresent, it was a popular term associated with women by the media to describe everything from women's clothing's to food. It suggested a feminine essence about how women should look and act. As Caryl Churchill says in her play Top Girls that a woman's sexuality, costumes, looks, personal desires can be easily manipulated to produce a desired effect in the patriarchal world.

The cult of daintiness was popular in the early $19^{\text {th }}$ century, partly, because it was supported by the home economics movement, which sought to change the idea of food from being organic to scientific. Laura Shapiro in her book Perfection Salad, argues that women involved in the home economics at the turn of the century wished to reconstruct food by using convenience foods and make them dainty for the women to consume, which eventually led to the decline of American home cooking into bland recipes overseen by homemakers with intentionally suppressed creativity. Laura Shapiro completes the thought with Something from the Oven, which portrays how a handful of women break through the conspiracies of the media corporations, reminding Americans of the actual virtue of fresh ingredients, combined with care. She argues that the idea of liberating women from the kitchen via modern appliances and convenience foods is like insulting them and showcasing that women are incapable of mastering the art of cooking. The author also talks about famous personalities like Betty Crocker who from being a confident businesswoman turned to a corner-cutting housewife. Julia Child, who taught women that they could do better in the kitchen, gave them useful tools and insisted on believing in themselves. Similarly, Sherrie A. Inness in Dinner Roles talks about how media influenced the women by using convenience foods and the modern appliances to remain in the kitchen. They surely did gave women some freedom from the mundane kitchen chores and spend some leisure time catering to their other needs, ensuring that women could not go into the outer world to work and make a career. The technologically-sophisticated kitchen was compared to the husband's workplace downtown, and cooking was being seen as a challenging and creative experience for women, about which the husband would rave in front of his friends. In her autobiography of Julia Child, Shapiro, talks about her journey from being a California party-girl to making a career in food heralding her way into the Culinary renaissance and becoming a chief icon in the American society. With her TV commercial The French Chef she convinced and taught the Americans to cook with confidence and eat with pleasure. Shapiro portrays a woman who was quintessentially American, whose openhearted approach to the kitchen was a lesson to live who became famous on the TV, in an era when cooking shows were not even popular, because Child had no artifice, she was just herself says, Shapiro.

\section{CONCLUSION}

Why do women have to do majority of the cooking? What role does food play in constructing our identities as men and women? The culinary literature of the fifties played an important role in answering these questions. They acted as a perfect rule book of the society to convey the gender roles and responsibilities divided on the basis of it. On one hand, they taught women to be feminine in every aspect of their life and on the other hand, they were taught to keep themselves subordinate and cater to the needs of the man. Inness in Dinner Roles writes that daintiness became a way to keep women in the kitchen by keeping them busy with the detailed luncheons. It was a perfect example which served as a visible sign of the invisible wealth to pursue the ideal middle-class stature, as daintiness was not affordable by the poor.

The Juvenile cookbooks taught girls not only cooking lessons but also how to use those skills in building other aspects of their lives. The lesson of cooking as a sacred experience for women has not died yet completely even today. As is the case in Top Girls by Caryl Churchill in which she talks about women who despite their hard work are always kept in a subordinated position. Women are expected to keep themselves in the household and even her tastes in subordination to those of a man. Very easily, the society intertwines cooking to a woman's sexuality, looks, personal desires and manipulates them into making kitchen their sole arena to showcase their artistic talents and creativity, keeping intact the unshakeable belief of cooking being women's natural responsibility that has been woven into the cultural fabric of the American society since its earliest years.

Despite the prodigious journey of the societal changes post both the World Wars, women had little choice when it came to kitchen duties. It was and still expected to be naturally a woman's responsibility. The convenience foods were not so convenient when it came to challenging the societal norms for the women, they were just used as a bait to keep women in the kitchen by giving them a little freedom but this freedom never really liberated women from the kitchen. The society and media made sure to keep women in the kitchen by introducing new recipes, technologies and most importantly toying with their 
emotions to keep them in the kitchen, ensuring they don't get a chance to invade into the capitalist world.

\section{REFERENCES}

[1] Sherrie A. Inness. (2001). Dinner Roles American Women and Culinary Culture

[2] Laura Shapiro. (2007). Julia Child

[3] Laura Shapiro. (2004). Something from the Oven: Reinventing Dinner in 1950'2 America, 2004

[4] Laura Shapiro. (1986). PerfectionSalad: Women and cooking at the turn of the century

[5] Caryl Churchill. (1982). Top Girls

[6] Ken Albala. (2012).Routledge International Handbook of Food Studies

[7] Ann Hodgman. (2004). What's for Dinner?.The Atlantic

[8] Noel Murray. (2004). Laura Shapiro: Something from the Oven: Reinventing Dinner in 1950s America

[9] Emmaline Smith. (2016). Dinner Roles: American Women and Culinary Culture

[10] Cassarino, Stacie. (2014). American Food Culture, the Language of Taste, and the Edible Image in TwentiethCentury Literature

[11] Dr. Christoph Houswitschka. (2005/06). Top Girls by Caryl Churchill

[12] New York: North Point Press. (1986).Review: Perfection Salad: Women and Cooking at the Turn of the Century, by Laura Shapiro

[13] Holly Williams. (2013). Culinary Culture: Food glorious food!, Independent 